\title{
Analysis of Energy Need and Adequacy of Athlete Based on Physical Activity Measurement Using Pedometer
}

\author{
$1^{\text {st }}$ Deny Yudi Fitranti \\ Department of Nutrition Science \\ Faculty of Medicine, Diponegoro \\ University \\ Semarang, Indonesia \\ denyyudi@gmail.com
}

\author{
$2^{\text {nd }}$ Fillah Fithra Dieny \\ Department of Nutrition Science \\ Faculty of Medicine, Diponegoro \\ University \\ Semarang, Indonesia \\ fillahdieny@gmail.com
}

\author{
$5^{\text {th }}$ Vintantiana Sukmasari \\ Department of Nutrition Science \\ Faculty of Medicine, Diponegoro \\ University \\ Semarang, Indonesia \\ vint916@gmail.com
}

\author{
$3^{\text {rd }}$ Choirun Nissa \\ Department of Nutrition Science \\ Faculty of Medicine, Diponegoro \\ University \\ Semarang, Indonesia \\ nissaeyong@gmail.com
}

\author{
$6^{\text {th }}$ Maria Dolorosa Sus Renata \\ Department of Nutrition Science \\ Faculty of Medicine, Diponegoro \\ University \\ Semarang, Indonesia \\ renatadolorosa@gmail.com
}

\author{
$4^{\text {th }}$ Hartanti Sandi Wijayanti \\ Department of Nutrition Science \\ Faculty of Medicine, Diponegoro \\ University \\ Semarang, Indonesia \\ hartantisandi@gmail.com
}

\begin{abstract}
Physical activity is an important component in measuring energy need of an athlete. Pedometer is a tool to estimate energy expenditure from physical activities based on footsteps. This study aims to analyze the differences of energy needed and adequacy on athlete based on physical activity measurement by using pedometer and calculation. This is an observational study with cross sectional design in 4 football school in Semarang. The samples of this study were 76 athletes aged 15-20 years old. The subject of study was selected by using consecutive sampling. Independent variable was energy expenditure from playing football measured by using pedometer and calculation. The dependent variable was energy need and adequacy. The data of food intake through recall of 3x24 hours. The means of energy adequacy based on energy expenditure from playing football is using calculation was $63,12 \pm 10,50 \mathrm{kcal}$, meanwhile by using pedometer was $70,57 \pm 12,70 \mathrm{kcal}$. The means of energy need based on energy expenditure from playing football is using calculation was higher than using pedometer, with the value of difference was $359 \mathrm{kcal}$. There was a difference in the means of energy need and adequacy based on energy expenditure from playing football by using calculation and pedometer.
\end{abstract}

Keywords- pedometer, energy adequacy, energy need, athlete, football

\section{INTRODUCTION}

Athletes must concern about their physical condition and health in order to perform optimally in all competition. High achievement in sport needs to be retained and improved. One of important factors to realize is through athlete's diet. The guidance of diet on athlete based on balanced nutrition which means that the energy intake is equal to the energy used for activity and exercise. The food intake of an athlete should be in accordance with the need for daily activity and exercise [1].

One of the sports that requires good nutrition management is football. Football is a sport that requires high energy and can be synchronized with energy needs for very heavy workers. Physical activity performed by athlete is running, kicking, jumping and sprinting with a fairly high percentage. Football athletes require energy 3800-3900 calories each day to perform various activities [2]. It was found frequently that energy adequacy in football athletes is not adequate. Research shows that as much as $41,7 \%$ energy adequacy level in adolescence football athletes in Denpasar is low [3]. The lack of nutritional intake in athletes resulted in low performance so that achievement was decreased.

The problem that often occurs in Indonesian athletes during the match is fatigue due to lack of energy reserves and high levels of lactic acid in the blood. Athletes need adequate energy intake during a match. Energy serves as a fuel that activates muscle contraction and maximizes athlete performance. Motion occurs in sports due to muscle contraction. Muscles can contract because of the energy release of ATP available in muscle cells. ATP in cells is limited in number and can be used as an energy source in just 1-2 seconds. Muscle contractions will continue if the reduced ATP is reformed. The re-establishment of ATP can be derived from the creatine phosphate, glucose, glycogen, and fatty acids [4].

The need for nutrients in athlete increases because of the large energy expenditure used for exercise activities. The nutritional need of athletes is individual based on gender of athlete, age, body weight, and physical activity consisting of 
exercise activity and daily activity [1]. Physical activity becomes an important component in the assessment of nutritional needs of athletes. There are several ways of determining the energy expenditure on physical activity. One of them by using a physical activity questionnaire. A physical activity questionnaire will record the daily and exercise activity of athletes and then calculations will be performed to get an estimation of energy expenditure. In addition, there is a way of measuring physical activity using a pedometer. This tool can be put at body part such as grips, wear as necklace or put in pocket. A pedometer is a tool for estimating energy expenditure by footsteps [5]. Measurement of energy expenditure on physical activity using a pedometer is able to determine the actual number of nutritional needs of athletes.

The tools widely used by sports nutrition practitioners in determining the energy expenditure during the activity are with a physical activity questionnaire. In other hand the measurement of physical activity using a pedometer has not been used. Based on this background, author was interested to do analysis on the measurement of physical activity by using a pedometer and calculations.

\section{MATERIALS AND METHODS}

This Study is an observational study with cross sectional design in 4 school of football that is Terang Bangsa, Ungaran Satria Kencana Serasi Semarang, Ekoprimafera Football Club (EPFC) and PSSI Team PORProv. The samples in this study were 76 subjects. The inclusion criteria in this study subjects were athletes aged 15-20 years, not being injured or attending medical care and willing to follow the research by filling out the Informed Consent form. The subjects were selected by consecutive sampling. Independent variable was physical activity from playing football measured by using pedometer and calculation. Dependent variable was energy need and adequacy. Subjects who met the inclusion criteria were taken food intake data and energy expenditure from playing football measured by using pedometer and calculation.

Energy needs are calculated from the sum of several components: basal energy, physical activity and specific dynamic action (SDA). This study calculated 2 energy needs. Energy need of A is the energy need calculated from the sum of basal energy, energy from daily activity, energy from playing football based on calculation, energy from other exercises and SDA [1]. The physical activity data of football exercise and other exercises was obtained through interviews using questionnaires. While the energy need of B is calculated from the sum of basal energy, energy from daily activity, energy from playing football based on pedometer, the energy from other exercises and SDA. Energy intake is the average amount of energy intake of food, beverages and supplements consumed by the subject each day obtained by using a 24-hour 3 -day recall method not in sequence [6]. Energy intake data is converted into kcal units calculated using nutrisurvey software. Energy adequacy is the ratio of the average energy intake of athletes to individual energy needs. There are 2 adequacy of energy that is energy adequacy of A based on energy need of A and energy adequacy of B based on energy need of B.

Physical activity is energy expenditure from playing football. This study calculated 2 energy expenditure from playing football that is measured by calculation and pedometer. Pedometer is an instrument to measure estimation of energy expenditure from physical activity based on footsteps. Pedometer used in this study was Omron HJ-313. Pedometers were worn around the athlete's neck during a football match.

Univariate analysis was conducted by presenting the data in the frequency distribution table of the variables. Bivariate analysis was conducted to find out the difference between independent variable with dependent variable. KolmogorovSmirnov normality test was conducted, the Wilcoxon Test was used to analyze the difference between the energy expenditure from playing football based on calculation and pedometer. Dependent $T$ test was used to analyze the difference of energy need and energy adequacy of athlete based on physical activity using calculation and pedometer. Data analysis using SPSS with $95 \%$ confidence degree $(\alpha=0,05)$.

\section{RESULTS AND DISCUSSIONS}

The numbers of subjects in this study were 76 football athletes. Football athletes who follow the study have an age range of 15-20 years. Subjects were dominated by 15 -year-old football athletes $(26,3 \%, \mathrm{n}=20$ subjects) and 16 years $(26,3 \%, \mathrm{n}=20$ subjects). While the subject with the least number of football athletes aged 19 years $(7,9 \%, n=6$ subjects).

Table 1 shows the mean body mass index (BMI) and the body fat percentage of the subjects was $20,7 \mathrm{~kg} / \mathrm{m}^{2}$ and $18,56 \%$. This shows that most athletes have a BMI and a normal body fat. BMI and body composition is one of the supporting performances of athletes. A study says that football athletes who have a normal BMI risk 13.2 times more fit than athletes who have overweight BMI status [7].

The average energy expenditure from playing football based on the calculation is $830,89 \mathrm{kcal}$, while pedometer was $471,89 \mathrm{kcal}$. It can be concluded that the average energy expenditure from playing football by using calculation was greater than pedometer. Energy expenditure from exercise is one of the components used to calculate total energy needs a day or total energy expenditure (TEE) [8]. Measuring the energy expenditure from exercise is difficult, because each individual has a different movement and the appropriate instruments are needed to be able to calculate the more appropriate energy expenditure [9]. A pedometer is a device that measures estimation of energy expenditure through the footsteps. According to research, pedometer was used to measure footsteps [10] and accurate instruments used in adolescents [11].

Based on Table 2, it is known that the player with a defensive midfielder has the highest energy expenditure of 499,65 kcal when compared with the player with another position. The striker's position also has a high energy expenditure, average at 496,55 kcal. The results of this study 
are in line with the study which states that the player in the position of the midfielder has the highest total mileage so that has a higher level of energy expenditure than the other players [12]. This can happen because the midfielder has the intensity of running or sprint higher than the other players [13]. In addition the midfielder has the task of two tasks at once, namely as defender and attack / regulator attack, and has a wider travel region than the players other positions [14].

Table 3 shows that $94.8 \%$ of football athletes have normal nutritional status, while 3 subjects had underweight and 1 subject had overweight. As many as $93.4 \%$ of football athletes have a normal body fat, 4 were underfat, and 1 subject was overfat. Percent body fat is one component of the body composition that affects the performance of athletes. The study states that the percentage of fat $(r=-0,670, p=0,024)$ of the body has a negative relationship with muscle strength, where muscle strength is one component of performance support and athlete performance [15].

TABLE 1: Characteristic of Subject

\begin{tabular}{|c|c|c|c|}
\hline Variable & Minimum & maximum & Mean \pm SD \\
\hline Body weight $(\mathrm{Kg})$ & 41,0 & 74,5 & $57,89 \pm 7,40$ \\
\hline Body height $(\mathrm{cm})$ & 152,2 & 182,0 & $167,10 \pm 6,30$ \\
\hline $\begin{array}{l}\text { Body Mass Index } \\
\left(\mathrm{Kg} / \mathrm{m}^{2}\right)\end{array}$ & 16,1 & 26,2 & $20,7 \pm 2,01$ \\
\hline Body Fat Percentage (\%) & 10,5 & 27,4 & $18,56 \pm 3,11$ \\
\hline $\begin{array}{l}\text { Energy expenditure from } \\
\text { playing football based on } \\
\text { calculation (kkal) }\end{array}$ & 562,67 & 1170,71 & $830,89 \pm 141,33$ \\
\hline $\begin{array}{l}\text { Energy expenditure from } \\
\text { playing football based on } \\
\text { pedometer (kkal) }\end{array}$ & 279 & 744 & $471,89 \pm 94,63$ \\
\hline Energy intake (kkal) & 1062,60 & 2995,50 & $2178,30 \pm 347,00$ \\
\hline Energy need of $\mathrm{A}^{\mathrm{a}}$ (kkal) & 2497,49 & 4541,68 & $3481,83 \pm 443,37$ \\
\hline Energy need of $\mathrm{B}^{\mathrm{b}}(\mathrm{kkal})$ & 2261.55 & 4147.11 & $3122,83 \pm 390,03$ \\
\hline $\begin{array}{l}\text { Energy adequacy of } \mathrm{A}^{\mathrm{c}} \\
(\%)\end{array}$ & 33,52 & 84,49 & $63,16 \pm 10,49$ \\
\hline $\begin{array}{l}\text { Energy adequacy of } \mathrm{B}^{\mathrm{d}} \\
(\%)\end{array}$ & 39,36 & 95,18 & $70,57 \pm 12,70$ \\
\hline
\end{tabular}

TABLE 2. Description of average energy expenditure of position in football

\begin{tabular}{|c|c|c|}
\hline Position & $\mathrm{n}$ & Mean energy expenditure \\
\hline Defender /back & 31 & 452,32 \\
\hline Center back & 13 & 416,31 \\
\hline Right back & 6 & 440,33 \\
\hline Left back & 6 & 481,67 \\
\hline Wing & 6 & 471,00 \\
\hline Midfielder & 34 & 482,31 \\
\hline Defending Midfielder & 20 & 499,65 \\
\hline Right wing & 8 & 477,62 \\
\hline Left wing & 6 & 469,67 \\
\hline Striker & 11 & 496,55 \\
\hline Total & 76 & \\
\hline
\end{tabular}

TABLE 3. Description of nutritional status, percent body fat and energy adequacy

\begin{tabular}{|c|c|c|}
\hline Variable & $\mathbf{n}$ & $\%$ \\
\hline \multicolumn{3}{|l|}{ Nutritional status } \\
\hline Underweight & 3 & 3,9 \\
\hline Normal & 72 & 94,8 \\
\hline Overweight & 1 & 1,3 \\
\hline \multicolumn{3}{|l|}{ Percent of body fat } \\
\hline Underfat & 1 & 1,3 \\
\hline Normal & 71 & 93,4 \\
\hline Overfat & 4 & 5,3 \\
\hline \multicolumn{3}{|c|}{ Energy adequacy based on } \\
\hline $\begin{array}{l}\text { adequate } \\
\text { low }\end{array}$ & 70 & 92,1 \\
\hline $\begin{array}{l}\text { Energy adequacy } \\
\text { energy need of } B^{b}\end{array}$ & 19 & 25,0 \\
\hline $\begin{array}{l}\text { adequate } \\
\text { low }\end{array}$ & 57 & 75,0 \\
\hline
\end{tabular}
higher proportion of subjects with lower adequacy $(92.1 \%)$ than energy adequacy based on energy need of B (75\%). The difference in the energy expenditure from exercise can affect the estimated total daily energy need or total energy expenditure (TEE). This causes a difference in the level of energy adequacy in athletes.

Based on Table 4 it is known that there are differences in energy expenditure from playing football, energy need and energy adequacy based on calculation and pedometer. Median energy expenditure from playing football based on calculation is higher than $(793.18 \mathrm{kcal})$ pedometer (492 kcal). The difference in energy expenditures is $301,18 \mathrm{kcal}$. The mean energy need based on energy expenditure from playing football by using calculation $(3841,77 \mathrm{kcal})$ is higher than pedometer $(3122,77 \mathrm{kcal})$. The difference in energy need based on energy expenditure from playing football by using calculation and pedometer is $358.99 \mathrm{kcal}$. The mean percentage of total energy adequacy based on energy need of A $(63,12 \%)$ is lower than energy adequacy based on energy need of $\mathrm{B}(70,57 \%)$. The percent difference in energy adequacy based on energy need $\mathrm{A}$ and $\mathrm{B}$ is $7.40 \%$.

Adequacy of nutritional intake in athletes is important because it affects the health and performance of athletes, especially adolescent athletes who are still in its physical growth [16]. In the determination of athlete's intake, physical energy activity measurements are used to calculate the total energy expenditure (TEE) estimates. TEE consists of three components: basal metabolic rate (BMR) or resting energy expenditure (REE), thermic effect of food (TEF), and activity energy expenditure (AEE) [8]. The measurement of physical activity during the exercise needs to be done in detail, including the frequency, intensity, and type of activity as these measurements will be taken into account in determining the AEE value and affecting the TEE value. The problem that arises so far is in determining a valid and reliable instrument in calculating physical activity during exercise. Due to the tool limitations. Questionnaires are the most commonly used tools although heart rate monitoring or movement is judged to be more accurate and reliable [9]. 
TABLE 4. Bivariate Analysis

\begin{tabular}{|c|c|c|c|}
\hline Variable & mean/median & $\Delta$ (delta) & $p$ \\
\hline $\begin{array}{l}\text { Energy expenditure from } \\
\text { playing football based on } \\
\text { calculation (kkal) } \\
\text { Energy expenditure from } \\
\text { playing football based on } \\
\text { pedometer (kkal) }\end{array}$ & 793,18 & \multirow[t]{3}{*}{301,18} & \multirow[t]{2}{*}{$0,001^{*}$} \\
\hline $\begin{array}{l}\text { Total energy need of A } \\
(\mathrm{kkal})^{\mathrm{a}}\end{array}$ & $3841,77 \pm 443,38$ & & \\
\hline $\begin{array}{l}\text { Total energy need of B } \\
(\mathrm{kkal})^{\mathrm{b}}\end{array}$ & $3122,77 \pm 390,03$ & & $0,001^{* *}$ \\
\hline energy adequacy of $\mathrm{A}(\%)^{\mathrm{c}}$ & $63,12 \pm 10,50$ & & \\
\hline $\begin{array}{l}\text { energy adequacy of B (\%) } \\
\text { d }\end{array}$ & $70,57 \pm 12,70$ & $7,40 \pm 3,67$ & $0,001^{\text {** }}$ \\
\hline $\begin{array}{l}\text { a Total energy need based on energy ex } \\
{ }^{\mathrm{b}} \text { Total energy need based on energy ex } \\
{ }^{\mathrm{c}} \text { Energy adequacy based on energy nec } \\
{ }^{\mathrm{d}} \text { Energy adequacy based on energy nec } \\
{ }^{*} \text { Wilcoxon, }{ }^{* *} \text { Dependent } \mathrm{t} \text { test }\end{array}$ & $\begin{array}{l}\text { diture from playing fo } \\
\text { liture from playing fo } \\
\text { A, } \\
\text { B. }\end{array}$ & $\begin{array}{l}11 \text { based on calculat } \\
l \text { based on pedomet }\end{array}$ & \\
\hline
\end{tabular}

This study shows that there is a difference of median energy expenditure from playing football based on calculation (793.18 kcal) and pedometer (492 kcal). According to recent study, the differences in physical activity values as measured by questionnaires and accelerometers can occur because the value of physical activity with the questionnaire only relies on the estimates of the subject and the value becomes higher than the value of the accelerometer [17]. These results are supported by study, which states that the use of accelerometer in calculating physical activity is more consistent than the use of questionnaires in males $(r=0.04)$ [18]. In addition to accelerometers, pedometers can also be used as an alternative in calculating the energy expenditure of physical activity in football athletes this can calculate energy through footsteps [10] and accurate instruments used in adolescents [11].

The difference in the proportion of energy adequacy based on energy need of A and based on energy need of B occurs due to different methods of measuring the energy expenditure during the exercise (playing football). The energy expenditure during exercise is one of the components used to estimate the energy needs during the day / TEE [8]. The balance of energy is the main thing that adolescence need to keep in mind to maintain optimal growth and development, as well as additional energy intake to replace energy expenditure due to daily exercise and competition [19]. Adolescent athletes with sustained energy deficiencies are at risk of impaired growth and development [20]. Energy intake is needed to maintain the physical endurance of the athlete. Research in Salatiga says that energy intake is positively associated with the physical endurance of te athlete $(p=0.046)$ [21]. The results is in line with the research which mentions that the energy intake before the game has asignificant effect on endurance athele $(p=$ $0,002)[22]$.

\section{CONCLUSION}

There was a difference in the mean of energy need and adequacy based on energy expenditure from playing football by using calculation and pedometer. The mean of energy need based on energy expenditure from playing football by using calculation was higher than using pedometer, with the value of difference was $359 \mathrm{kcal}$. For the athlete's food service department, it is advisable to consider the pedometer in determining the nutritional needs of athletes. It is important to determine the Total Energy Expenditure (TEE) that suits the actual needs of the athlete in order to avoid underestimated or overestimated total energy needs.

\section{REFERENCES}

[1] Ita, S, "How to determine energy needs an athlete" IEEE Trans. Cara menentukan kebutuhan gizi seorang atlet, Jurnal Pendidikan Jasmani Olahraga dan Kesehatan. 2014; 2(1): 87-91.

[2] Fink H.H, Burgon L.A, Mikesky A.E, Practical Applications in Sport Nutrition. Boston : Jones and Bartlett Publishers. 2006.

[3] Karyamitha NLG, Adhi KT, "Level of nutrition adequacy, physical activity and nutritional status of young men athletes soccer senior high school in Denpasar 2011" IEEE Trans. Tingkat kecukupan gizi, aktivitas fisik, dan status gizi atlet sepak bola remaja putra sekolah menengah atas (SMA) negeri di kota Denpasar tahun 2011), Medicina, 2012; 43: 95102.

[4] William MH, Nutrition for Health Fitness and Sport, New York: McGraw Hill Companies. 2007

[5] Yulistiawan. AA, Setiawan I, Sumardi, "Counter steps tool (Pedometer) with magnitude methods and variance threshold" IEEE Trans. Alat penghitung langkah (Pedometer) dengan metode magnitude dan variance threshold, Fakultas Teknik Universitas Diponegoro. 2012. Unpublished.

[6] Gibson RS, Principles of Nutritional Assessment second edition, New York : Oxford University Press. 2005. p 41-6.

[7] Setiowati, Anies, "Relationship of body mass index, percent body fat and nutrient intake with muscle strength" IEEE Trans. Hubungan indeks massa tubuh, persen lemak tubuh, asupan zat gizi dengan kekuatan otot, Jurnal Media Ilmu Keolahragaan Indonesia. 2014.4(1): 32-38.

[8] Ndahimana D, Enkyung Kim, "Measurement methods for physical activity and energy expenditure: a review. Clinical Nutrition Research. 2017.6(2): 68-80

[9] Mindell JS, Coombs N,Stamatakims E, "Measuring physical activity in children and adolescents for dietary survey: practicalities, problems and pitfalls. Proccedings of the Nutrition Society. 2014. p:1-8

[10] Crouter S, Schneider P, Karabulut M, Bassett DR, "Validity of 10 electronic pedometers for measuring steps, distance, and energy cost." Journal of the American College of Sport Medicine. 2003.p:1455-1460.

[11] Jago R, Watson K, Baranowski T, Zakeri I, Sunmi Yoo, Baranowski J, Conry K, "Pedometer reliability, validity and daily activity targets among 10-to-15 year-old Boys," Journal of Sports Sciences. 2006. 24(3): 241-251.

[12] Barron D, Atkins S, Edmundson C, Fewtrell D, "Accelerometer derived load according to paying position in competitive youth soccer," International Journal of Performance Analysis in Sport. 2014. 14: 734743.

[13] Di Salvo, V. Gregson W, Atkinson G, Tordoff P, Drust B,"Analysis of high intensity activity in premier league soccer," International Journal Sports and Medicine. 2009. 30: 205-212.

[14] Di Salvo V, Baron R, Tschan H, Calderon Montero FJ, Bachl N, Piggozi $\mathrm{F}$, "Performance characteristics according to playing position in elite soccer," International Journal Sport and Medicine. 2007. 28: 222-227.

[15] Bryantara, OK, "Factors that are associated to physical fitness (VO2 Max) of football athletes" IEEE Trans. Faktor yang berhubungan dengan kebugaran jasmani, ( $\mathrm{VO}_{2}$ Maks) atlet sepak bola)," 2016. 4(2): 237-249. 
[16] Carlsohn A, Rosenberger F, Cassel M, Weber J, Guzman A, Mayer F, "Physical activity levels to estimate the energy requirement of adolescent athletes. pediatric exercise science," 2011. 23: 261-269.

[17] Hagstromer M, Ainsworth B, Oja P, Sjostrom M, "Comparison of subjective and an objective measure of physical activity in a population sample." Journal of Physical Activity and Health. 2010. 7: 541-550.

[18] Skender S, Ose J, Claude J, Paskow M, Bruhman B, Siegel E, Steindorf $\mathrm{K}$, Ulrich CM, "Accelerometry and physical activity quetionnaires - a systematic review," BMC Public Health. 2016. 16: 515-524.

[19] Briggs M, Cockburn E, Rumbld P, Rae G, Stevenson E, Russel M.. Assessment of energy intake and energy expenditure of male adolescent academy-level soccer players during a competitive week," Nutrients. 2015. 7: 8392-8401.
[20] Daly R, Bass S, "Does training affect growth?," The Physician and Sportmedicine. 2002. 30(10): 21-29

[21] Shaleh MH, Sartono A, Kusuma HS, "Relationship levef of energy and protein consumption with imunity an atheletes in training and education center for football student Salatiga" IEEE Transl. Hubungan tingkat konsumsi energi dan protein dengan daya tahan tubuh pada atlet pusat pendidikan dan latihan pelajar sepakbola salatiga", Jurnal Gizi Universitas Muhammadiyah Semarang. 2014. 3(2): 10-16.

[22] Penggalih M, Huriyati E, "Lifestyle, nutrition status, and stamina an athletes in a football club " IEEE Transl. Gaya hidup, status gizi dan stamina atlet pada sebuah klub sepakbola), Berita Kesehatan Masyarakat. 2007. 23(4): 192-199. 